\title{
An empirical study on the impact of operating risk on structure capital and profitability in Iranian banking sector
}

\author{
Mohammad Taghi Samadi
}

Iran Banking Institute, Tehran, Iran

\begin{tabular}{|c|c|}
\hline A R T I C L E I N F O & A B S T R A T \\
\hline $\begin{array}{l}\text { Article history: } \\
\text { Received December 25, } 2011 \\
\text { Received in Revised form } \\
\text { March, 25, } 2012 \\
\text { Accepted } 24 \text { April } 2012 \\
\text { Available online } \\
\text { April } 292012 \\
\text { Keywords: } \\
\text { Operating risks } \\
\text { Profitability }\end{array}$ & $\begin{array}{l}\text { Banking system plays an important role in boosting the economy and when they become } \\
\text { profitable, they could help industries more efficiently. The proposed study of this paper } \\
\text { attempts to investigate the effects of operating risk and capital structure on profitability of } \\
\text { banking industry. The proposed study of this paper includes } 17 \text { commercial banks, which were } \\
\text { active from } 2006 \text { to } 2010 \text { in Iran and the results of the study indicate that although there was a } \\
\text { positive relationship between capital structure and profitability but there was no meaningful } \\
\text { relationship between operating risk and capital structure. In addition, the results of our study } \\
\text { mention that operating risks negatively impacts profitability and economic figures do not have } \\
\text { any influence on profitability, operating risks and capital structure. }\end{array}$ \\
\hline
\end{tabular}

Capital structure

Structural equations model

\section{Introduction}

During the past few years, there has been some economical turmoil in world's economies. Many firms have faced with financial difficulties and there was a shortage on cash flow in various industries. Banking system has been considered as the main source of economies since they are the primary sources of financial assistance in terms of loans, line of credit, etc. Banking system must always look for possible ways on reducing risks in their systems in an attempt to prevent any financial crises (Gallo et al., 1996). Dietrich \& Wanzenried (2011) investigated the effects of 2008-financial crises on the profitability of Switzerland banks before and during the crisis and reported that banks could have prevented such crises a head of time, should they have been faithful to their rules and regulations. Regulations are normally set to immune banks from any unwanted accidents and a good discipline on rules and regulations could significantly contribute to the success of banking systems. Regulations in each country also play an important role in either increasing or decreasing the profitability of banks. García-Herrero et al. (2009) investigated why Chineese banks do not report much profitability on their statements. They found some negative impact for China's development banks, which are fully 
state-owned. Instead, more market-oriented banks, such as joint-stock commercial banks, were more profitable, which again points to the influence of government intervention in explaining bank performance in China. Joh (2003) studied Corporate governance and firm profitability based on some evidences from Korea before and after financial crises in 2001.

During the past two decades, there have been tremendous efforts on detecting important items influencing efficiency of banks. One of the most popular methods for measuring the performance of banking system is to use data envelopment analysis (DEA). In DEA method, there are normally some inputs and some outputs, which are either financially measureable or not and the relative efficiencies of various units are compared using a linear programming approach. Taylor et al. (1997) used DEA technique to measure the relative efficiencies of some Mexican banks. Lin et al. (2003) performed a comprehensive study on risk capital adequacy in evaluating on insolvency-risk and financial performances in Taiwan's banking industry. Hund et al. (2010) studied the uncertainty components on average profitability and the impact of diversified discount.

Kosmidou (2006) proposed a multivariate analysis of the financial characteristics of foreign and domestic banks in the UK. Kosmidou et al. (2007), in other work, investigated domestic and multinational factors of foreign bank profits for case study of Greek banks operating abroad. They reported that the profitability of the parent bank and the operating experience of its host nation subsidiaries had a positive influence on the profits of Greek banks abroad, whereas subsidiary bank size had a negative impact. Westman (2011) investigated the effect of management and board ownership on profitability in banks with various strategies by examining the joint impact of ownership and strategy on profitability in European banks and reported that management ownership has a positive influence on profitability in non-traditional banks, which are difficult to monitor. She also concluded that board ownership positively influenced on profitability in traditional banks, where monitoring incentives were reduced. Ben Naceur and Kandil (2009) investigated the impact of capital requirements on banks' cost of intermediation and performance for a case of Egypt. The results indicated that bank-specific characteristics including bank capitalization and credit risk had a positive and significant influence on banks' net interest margin, cost efficiency, and profitability. Chen \& Liao (2011) investigated the impact of governance and supervision on the performance of domestic and foreign banks. They found that foreign banks were more profitable than domestic banks when they operated in a host country whose banking sector was less competitive and when the parent bank in the home country was highly profitable. Rossi et al. (2009) investigated on how loan portfolio diversification could impact risk, efficiency and capitalization by considering managerial behavior for

some Austrian banks. They reported that, although diversification negatively influences cost efficiency, it increases profit efficiency and reduces banks' realized risk.

In this paper, we present an empirical study on some Iranian banks for measuring the impact of operating risk on some financial figures. The proposed model of this paper first presents details of survey in section 2 and the results of our investigation are given in section 3. Finally, concluding remarks are given in the last to summarize the contribution of this paper.

\section{The proposed study}

The proposed study of this paper selects 17 commercial banks, which have been actively operating from 2006 to 2010. We use four variables including capital structure, profitability, operating risk and macroeconomic figures. For each factor, we consider between one to four attributes and measure their relationships using statistical observations.

\subsection{Capital structure}

In this paper, there are four variables including operating risk, macroeconomic figures, capital structure and profitability and each variable also includes between one to four attributes. 
The mean and standard deviation of equity ratio are 2.105 and 0.888 , respectively and it has positive skew and strain. The skew coefficient is greater than 1.96, which means the distribution is not symmetric. The mean and standard deviation of debt ratio are 4.408 and 0.434 , respectively and it has skew deviation and coefficient of strain of greater than 1.96, which means the distribution is not symmetric and the meaningful deviation means the distribution is more like normal. The negative skewness of this variable means there are some data on the left side and the positive skewness means the distribution is taller than normal. Table 1 shows the results.

Table 1

Descriptive data associated with capital structure of banks

\begin{tabular}{lcccccccc}
\hline & & & & & & \multicolumn{3}{c}{ Coefficient deviations } \\
Variables & Number & Mean & Std dev. & Variance & Skew & Strain & Skew & Strain \\
\hline Equity ratio & 85 & 2.105 & 0.888 & 0.788 & 0.905 & 0.872 & 3.467 & 1.687 \\
Liability ratio & 85 & 4.408 & 0.434 & 0.189 & -5.775 & 40.209 & -22.113 & 77.810 \\
\hline
\end{tabular}

\subsection{Operating risk}

Operating risk has one attribute calculated using logarithm. Operating risk maintains a mean of 1.234 and standard deviation of 0.135 with positive skew and negative strain. The skew ratio is greater than 1.96, which means the distribution is not symmetric and strain coefficient is less than absolute value of 1.96, which means the distribution is not deviated from normal distribution. Table 2 shows details of the results.

Table 2

Descriptive data associated with operating risk

\begin{tabular}{lcccccccc}
\hline & & & & & & \multicolumn{3}{c}{ Coefficient deviations } \\
Variables & Number & Mean & Std dev. & Variance & Skew & Strain & Skew & Strain \\
\hline Equity ratio & 85 & 1.234 & 0.135 & 0.018 & -1.101 & 0.596 & -4.216 & 1.154 \\
\hline
\end{tabular}

\subsection{Profitability}

Profitability has three attributes including profit margin, return on assets (ROA) and return on equity (ROE). which are calculated using logarithm. Profitability maintains a mean of 2.934 and standard deviation of 1.927, which has a negative skew and positive strain. The skew ratio is greater than 1.96, which means the distribution is not symmetric and strain coefficient is less than absolute value of 1.96. It means the distribution is not deviated from normal distribution. ROA maintains a mean of 0.259 and standard deviation of 1.404, which maintains negative skew and positive strain. Again, all criteria means the distribution is not deviated from normal distribution. Table 3 shows details of the results. In addition, ROA maintains a mean of 2.227 and standard deviation of 1.295, which maintains negative skew and positive strain. Again, all criteria means the distribution is not deviated from normal distribution. Table 3 shows details of the results.

Table 3

Descriptive data associated with Profitability

\begin{tabular}{lcccccccc}
\hline & & & & & & \multicolumn{3}{c}{ Coefficient deviations } \\
Variables & Number & Mean & Std dev. & Variance & Skew & Strain & Skew & Strain \\
\hline Profit margin & 85 & 1.234 & 0.135 & 0.018 & -1.101 & 0.596 & -4.216 & 1.154 \\
\hline ROA & 85 & -0.259 & 1.404 & 1.971 & -1.119 & 0.713 & -4.284 & 1.379 \\
\hline ROE & 85 & 2.227 & 1.295 & 1.676 & -0.905 & 0.303 & -3.465 & 0.587 \\
\hline
\end{tabular}

\subsection{Economic indices}

Economic index includes four attributes including economic current and fixed growth rates, inflation rate and unemployment rate. Using a similar argument, we can conclude that all four figures can be estimated with normal distribution. Table 4 shows details of the results. 
Table 4

Descriptive data associated with economic figures

\begin{tabular}{lcccccccc}
\hline & & & & & & \multicolumn{3}{c}{ Coefficient deviations } \\
Variables & Number & Mean & Std dev. & Variance & Skew & Strain & Skew & Strain \\
\hline Fixed GDP & 85 & 1.018 & 1.162 & 0.351 & -0.795 & -1.015 & -3.044 & -1.964 \\
\hline Current GDP & 85 & 2.782 & 0.654 & 0.428 & -1.126 & -0.305 & -4.312 & -0.591 \\
\hline Inflation rate & 85 & 2.726 & 0.312 & 0.097 & 0.562 & -1.146 & 2.152 & -2.217 \\
\hline Unemployment rate & 85 & 2.407 & 0.053 & 0.003 & -0.111 & -1.627 & -0.425 & -3.149 \\
\hline
\end{tabular}

\section{The results}

Note that we have gathered the necessary data from 17 banks within 5 years period and we have 85 observations. The proposed study of this paper attempts to find the relationships among ten different attributes. In terms of macroeconomic attributes, all t-student values associated with factor loading are greater than 1.96, which are meaningful when the level of significance is 0.05 . In terms of profitability, there are three attributes of profit margin, ROA and ROE and, again, all t-student values associated with factor loading are greater than 1.96, which are meaningful when the level of significance is 0.05 . Capital structure includes two attributes of equity and liability ratios and all tstudent values are meaningful, which means there are meaningful relationships among these components. Table 5 shows details of our calculations.

Table 5

The results of factor loading and t-student

\begin{tabular}{llllll}
\hline Attribute & Index & Coefficient & mean & $\begin{array}{l}\text { Standard } \\
\text { deviation }\end{array}$ & t-student \\
\hline CA-ST & LNER & -0.8907 & -0.6234 & 0.0371 & -24.0030 \\
& LNLR & 0.9445 & 0.9430 & 0.0228 & 41.4193 \\
\hline O-RISK & LNOR & 1.0000 & 1.0000 & 0.0000 & 0.0000 \\
\hline \multirow{3}{*}{ PROFIT } & LNPM & 0.9287 & 0.8781 & 0.1479 & 6.2781 \\
& LNROA & 0.4750 & 0.5455 & 0.2239 & 2.1576 \\
& LNROE & 0.6571 & 0.6185 & 0.1801 & 3.6480 \\
\hline \multirow{3}{*}{ MACRO-E } & LNEGR1 & 0.8686 & 0.7607 & 0.2024 & 4.2918 \\
& LNEGR2 & 0.9201 & 0.8086 & 0.1980 & 4.6469 \\
& LNIR & -0.8654 & -0.8328 & 0.2117 & -4.0869 \\
& LNER & 0.6776 & 0.7162 & 0.2037 & 3.3270 \\
\hline
\end{tabular}

Our investigations indicate that macroeconomic figures do not influence other attributes but capital structure influences profitability and operating risk, significantly and the statistical observations are meaningful. The other observation is that capital structure directly influences on operating risk in reverse direction. The coefficient of profitability shows that approximately 0.377 of profitability changes are described by operating risk, capital structure and macroeconomics attributes.

Table 6

The results of the relationships between independent and dependent variables

\begin{tabular}{cccccc}
\hline $\begin{array}{l}\text { Independent } \\
\text { variable }\end{array}$ & $\begin{array}{l}\text { Dependent } \\
\text { variable }\end{array}$ & Coefficient & Mean & $\begin{array}{c}\text { Standard } \\
\text { deviation }\end{array}$ & t-statistic \\
\hline CA-ST & PROFIT & 0.6600 & .05990 & 0.2237 & 2.9501 \\
O-RISK & PROFIT & -0.2390 & -0.2089 & 0.0986 & -2.4250 \\
MACRO & PROFIT & -0.0160 & -0.0994 & 0.0815 & -0.1964 \\
MACRO & O-RISK & 0.1220 & 0.1089 & 0.0703 & 1.7203 \\
MACRO & CA-ST & -0.0930 & -0.1094 & 0.0629 & -1.4785 \\
O-RISK & CA-ST & 0.3730 & 0.4110 & 0.1250 & 2.9839 \\
\hline
\end{tabular}


Table 6 shows details of our results. As we can observe, when we remove macroeconomic factors, all other relationships are meaningful. Next, we present six hypothesis associated with the proposed study of our paper and the results of our tests are summarized in Table 7.

\section{Table 7}

The results of six hypotheses

\begin{tabular}{|c|c|c|}
\hline Hypothesis & t-student result & Result \\
\hline $\begin{array}{l}\mathrm{H}_{0} \text { : Capital structure has no impact on } \\
\text { profitability }(\beta \leq 0) \\
\mathrm{H}_{0} \text { : Capital structure has positive } \\
\text { impact on profitability }(\beta>0) \text {. }\end{array}$ & $\beta_{C A, P R}=.66 \quad \mathrm{t}_{\mathrm{ob}}=2.95>t_{c}=1.96 \rightarrow \mathrm{p}<.05$ & $\begin{array}{l}\mathrm{H}_{0} \text { is } \\
\text { rejected. }\end{array}$ \\
\hline $\begin{array}{l}\mathrm{H}_{0} \text { : Capital structure has no impact on } \\
\text { operating risk }(\beta \geq 0) \\
\mathrm{H}_{0} \text { : Capital structure has negative } \\
\text { impact on operating risk }(\beta<0) \text {. }\end{array}$ & $\beta_{C A, R I S K}=.373 \mathrm{t}_{\mathrm{ob}}=2.984>t_{c}=1.96 \rightarrow \mathrm{p}<.05$ & $\begin{array}{l}\mathrm{H}_{0} \text { is } \\
\text { rejected. }\end{array}$ \\
\hline $\begin{array}{l}\mathrm{H}_{0} \text { : Operating risk has no impact on } \\
\text { profitability }(\beta \geq 0) \\
\mathrm{H}_{0} \text { : Operating risk has negative impact } \\
\text { on profitability }(\beta<0) \text {. }\end{array}$ & $\beta_{R I S K, P R}=-.239 \mathrm{t}_{\mathrm{ob}}=-2.425>t_{c}=-1.96 \rightarrow \mathrm{p}<.05$ & $\begin{array}{l}\mathrm{H}_{0} \text { is } \\
\text { rejected. }\end{array}$ \\
\hline $\begin{array}{l}\mathrm{H}_{0} \text { : Macroeconomic factors have no } \\
\text { impact on profitability }(\gamma=0) \text {. } \\
\mathrm{H}_{1} \text { : Macroeconomic factors have no } \\
\text { impact on profitability }(\gamma \neq 0)\end{array}$ & $\beta_{E C O, P R}=-.016 \mathrm{t}_{\mathrm{ob}}=-.196<\left|t_{c}\right|=|1.96| \rightarrow \mathrm{p}>.05$ & $\begin{array}{l}\mathrm{H}_{0} \text { is } \\
\text { accepted. }\end{array}$ \\
\hline $\begin{array}{l}\mathrm{H}_{0} \text { : Macroeconomic factors have no } \\
\text { impact on capital structure }(\gamma=0) \text {. } \\
\mathrm{H}_{1} \text { : Macroeconomic factors have no } \\
\text { impact on capital structure }(\gamma \neq 0)\end{array}$ & $\beta_{E C O, C A}=-.093 \mathrm{t}_{\mathrm{ob}}=-1.479<\left|t_{c}\right|=|1.96| \rightarrow \mathrm{p}>.05$ & $\begin{array}{l}\mathrm{H}_{0} \text { is } \\
\text { accepted. }\end{array}$ \\
\hline $\begin{array}{l}\mathrm{H}_{0} \text { : Macroeconomic factors have no } \\
\text { impact on operating risk }(\gamma=0) \text {. } \\
\mathrm{H}_{1} \text { : Macroeconomic factors have no } \\
\text { impact on operating risk }(\gamma \neq 0)\end{array}$ & $\beta_{E C O, C A}=-.093 \mathrm{t}_{\mathrm{ob}}=-1.479<\left|t_{c}\right|=|1.96| \rightarrow \mathrm{p}>.05$ & $\begin{array}{l}\mathrm{H}_{0} \text { is } \\
\text { accepted. }\end{array}$ \\
\hline
\end{tabular}

As we can observe from the results of Table 7, the first three hypotheses have been confirmed and the other three hypotheses were not confirmed. Therefore, we can conclude that there was a positive relationship between capital structure and profitability but there was no meaningful relationship between operating risk and capital structure. In addition, the results of our study mention that operating risks negatively impacts profitability and economic figures do not have any influence on profitability, operating risks and capital structure.

\section{Conclusion}

In this paper, we have performed an empirical study to find the relationship between operating risk and other important macroeconomic as well as financial figures such as profitability, profit margin and structure capital. The results of our study indicate that although macroeconomic factors such as inflation rate, GDP growth and unemployment have no impact on operating cost but that there was a positive relationship between capital structure and profitability. The results of our study confirmed that operating risks negatively impacts profitability and economic figures do not have any influence on profitability, operating risks and capital structure. 


\section{Acknowledgment}

The authors would like to thank the officials of Tehran Stock Exchange and all other people who helped us complete this survey.

\section{References}

Ben Naceur, S., \& Kandil, M. (2009). The impact of capital requirements on banks' cost of intermediation and performance: The case of Egypt. Journal of Economics and Business, 61(1), 70-89.

Chen, S.H., \& Liao, C.C. (2011). Are foreign banks more profitable than domestic banks? Home- and host-country effects of banking market structure, governance, and supervision. Journal of Banking \& Finance, 35(4), 819-839.

Dietrich, A., \& Wanzenried, G. (2011). Determinants of bank profitability before and during the crisis: Evidence from Switzerland. Journal of International Financial Markets, Institutions and Money, 21(3), 307-327.

Gallo, J.G., Apilado, V.P., \& Kolari,J.W. (1996). Commercial bank mutual fund activities: Implications for bank risk and profitability. Journal of Banking \& Finance, 20(1), 1775-1791.

García-Herrero, A., Gavilá, S., \& Santabárbara, D. (2009). What explains the low profitability of Chinese banks?. Journal of Banking \& Finance, 33(11), 2080-2092.

Hund, J., Monk, D., \& Tice, S. (2010). Uncertainty about average profitability and the diversification discount. Journal of Financial Economics, 96(3), 463-484.

Joh, S.W. (2003). Corporate governance and firm profitability: evidence from Korea before the economic crisis. Journal of Financial Economics, 68(2), 287-322.

Kosmidou, K., Pasiouras, F., Zopounidis, C., \& Doumpos, M. (2006). A multivariate analysis of the financial characteristics of foreign and domestic banks in the UK. Omega, 34(2), 189-195

Kosmidou, K., Pasiouras, F., \& Tsaklanganos, A. (2007). Domestic and multinational determinants of foreign bank profits: The case of Greek banks operating abroad. Journal of Multinational Financial Management, 17(1), 1-15.

Lin, S.L., Penm, J.H.W., Gong, S.C., \& Chang, C.S. (2005). Risk-based capital adequacy in assessing on insolvency-risk and financial performances in Taiwan's banking industry. Research in International Business and Finance, 19(1), 111-153.

Rossi, S.P.S, Schwaiger, M.S., \& Winkler, G. (2009). How loan portfolio diversification affects risk, efficiency and capitalization: A managerial behavior model for Austrian banks. Journal of Banking \& Finance, 33(12), 2218-2226

Taylor, W.M., Thompson, R.G., Thrall, R.M., \& Dharmapala, P.S. (1997). DEA/AR efficiency and profitability of Mexican banks a total income model. European Journal of Operational Research, 98(2), 346-363.

Westman,H. (2011). The impact of management and board ownership on profitability in banks with different strategies. Journal of Banking \& Finance, 35(12), 3300-3318. 